\title{
Digestibilities of a Commercial Feed Based on Liquid Streptomyces Solubles (LSS) and Cane Molasses and of Condensed Molasses Solubles $(\mathrm{CMS})^{1,2}$
}

\author{
Bernardo Vallejo and Paul F. Randel ${ }^{3}$
}

\begin{abstract}
Two digestibility trials were conducted by the difference method, with 4 steers and 5-day periods of total feces collection, to evaluate two liquid feeds: 1) Solub Mol [a commercial product composed of $70 \%$ liquid streptomyces solubles and $30 \%$ cane molasses, with $44.2 \%$ dry matter (DM)] and 2) condensed molasses solubles or rum distillery stillage, with 53.3\% DM. Mean digestibilities found for Solub Mol were: DM, $72.0 \pm 2.2 \%$; organic matter (OM), $71.1 \pm 2.3 \%$; calories, $72.5 \pm 2.2 \%$; and crude protein (CP), $32.2 \pm$ $2.4 \%$. The contents of digestible energy (DE) and digestible crude protein (DCP) were $3.22 \mathrm{kcal} / \mathrm{g}$ and $4.0 \%$, respectively, in the DM. True digestibility of the CP was estimated as $58.3 \pm 2.6 \%$, corresponding to $7.1 \%$ true DCP in the DM. Solub Mol can be classified as a concentrated source of DE, but its nitrogenous fraction is poorly digested. Mean digestibilities determined in CMS were DM, $50.3 \pm 2.6 \%$; OM, $43.7 \pm 3.6 \%$, calories, $47.7 \pm 3.7 \%$; and $\mathrm{CP}, 40.6 \pm 5.6 \%$. DE and DCP contents in the DM were $1.76 \mathrm{kcal} / \mathrm{g}$ and $3.5 \%$, respectively. Estimated true CP digestibility was $75.4 \pm 6.4 \%$, corresponding to $6.5 \%$ true DCP in the DM. Condensed rum stillage is a fair source of energy and protein for cattle.
\end{abstract}

\section{INTRODUCTION}

The high cost of feeds, especially concentrates, is one of the principal problems of the cattle industry in Puerto Rico. The vast majority of the concentrates used are imported, while possible local feed resources, such. as industrial byproducts, are not fully utilized.

Liquid streptomyces solubles (LSS) is obtained as a residue in the microbiological production of the antibiotic, erythromycin, in a factory located in Barceloneta, P.R. The use of this material on a commercial scale as a liquid feed for dairy cattle began in late 1977. Shortly thereafter, the commercial formula was changed to a mixture of 70\% LSS and 30\% cane molasses, sold under the tradename Solub $\mathrm{Mol}^{4}$. Another industrial

${ }^{1}$ Manuscript submitted to Editorial Board August 12, 1980.

${ }^{2}$ Data taken from a thesis submitted by the senior author to the Graduate School of the Mayagüez Campus, University of Puerto Rico.

${ }^{3}$ Extension Agent and Nutritionist, respectively, Cooperative Extension Service and Agricultural Experiment Station, College of Agricultural Sciences, Mayagüez Campus, University of Puerto Rico.

4 Trade names in this publication are used only to provide specific information. Mention of a trade name does not constitute a warranty of equipment or materials by the Agricultural Experiment Station of the University of Puerto Rico, nor is this mention a statement of preference over other equipment or materials. 
byproduct, which is generated in huge quantities and represents an environmental pollution problem, is rum distillery stillage. Part of the total output of this waste material is submitted to a process of condensation, which facilitates its handling and storage. In this form it is known as condensed molasses solubles (CMS).

The present study was conducted to determine the digestibility for cattle of these two liquid industrial byproducts, when incorporated into a mixed ration in the highest feasible proportions.

\section{MATERIALS AND METHODS}

Two digestibility trials were conducted with 4 Holstein and Brown Swiss steers housed in collection stalls. In trial 1 the digestibility of Solub Mol was determined by the difference method ${ }^{5}$, the basal ration was pangolagrass hay (Digitaria decumbens), ground in a hammer mill through a $6.35 \mathrm{~mm}$ screen. During phase 1 , the ration consisted of a mixture of Solub Mol absorbed in the hay. Different levels of Solub Mol were tested until the maximum proportion accepted by the animals with no adverse digestive effects was established. The humid combination selected was $45 \%$ Solub $\mathrm{Mol}$ and 55\% hay. The two ingredients were hand mixed as homogeneously as possible through a screen with $12.7 \mathrm{~mm}$ square openings. On a dry matter (DM) basis the mixture contained $29 \%$ Solub Mol and 71\% hay. Voluntary intake was determined during 1 week of ad libitum feeding. Thereafter, the daily ration was restricted to approximately $90 \%$ of ad libitum intake, allowances being calculated relative to a preliminary liveweight determination as $55 \mathrm{~g}$ of $\mathrm{DM} / \mathrm{kg}^{.75}$. The daily ration was divided into two equal portions. No feed refusals were observed during the entire period of restricted feeding. Adjustment to the limited ration was permitted for 7 days, followed by 5 days of total feces collection. At each collection a representative sample of feces was taken and dried at $80^{\circ} \mathrm{C}$ for determining its DM content; thus daily output of fecal DM was calculated. The daily samples of feces from each animal were combined in aliquot proportions for chemical analysis.

During phase 2, Solub Mol was eliminated from the ration, while the amount of hay fed remained constant. Therefore, the animals received only $71 \%$ as much DM as in phase 1 . A quantity of water equivalent to that supplied previously by Solub Mol was incorporated into the ground hay as uniformly as possible. This added water served to prevent respiratory irritations and to facilitate handling and consumption of this bulky and dusty feed. Again there was a 7-day period of adjustment to the ration and then 5 days of fecal collection.

\footnotetext{
${ }^{5}$ Lloyd, L. E., B. E. McDonald and E. W. Crampton, 1978. Fundamental of Nutrition. 2nd. ed. W. H. Freeman and Company, San Francisco.
} 
During both collection periods, a sample was taken from each bale of hay used. All of the Solub Mol needed was drawn from a single drum, supplied by the manufacturer ${ }^{6}$. The DM percentages of hay and Solub Mol samples were determined by drying at $80^{\circ} \mathrm{C}$. These and also the feces samples were analyzed for ash by inicineration at $550^{\circ} \mathrm{C}$, for crude protein $(\mathrm{CP})$ by a macro-Kjeldahl method ${ }^{7}$, and for heat of combustion by means of a Parr adiabatic bomb calorimeter.

The coefficients of digestibility obtained for each fraction were used to calculate means, standard errors and ranges which encompass the correct digestibility with $95 \%$ confidence ${ }^{5}$. In addition to apparent digestibility, an estimate was made of true digestibility of the CP fraction, by assuming a value for metabolic fecal nitrogen (MFN).

Liveweights of the animals were redetermined on the second day of adjustment of phase 1 and again, 22 days later, at the end of phase 2, to assess the effects of the experimental regime on physical condition.

In trial 2 the digestibility of CMS was determined by procedures very similar to those of the preceding trial. The method of digestibility by difference was implemented using ground stargrass hay (Cynodon nlemfuensis) as the basal ration. During phase 1, the ration consisted of a mixture of $40 \%$ CMS and $60 \%$ hay, which represented the highest proportion of CMS tolerated by the animals. The corresponding proportions on a dry basis were $29 \%$ and $71 \%$ (by coincidence, the same as in trial 1 ). The daily ration was limited to $90 \%$ of the ad libitum intake of each individual. One of the steers injured a front leg, and required several days outside of the collection stall to recuperate; thus this animal's progress through the two experimental phases was delayed. Small. feed refusals were sometimes encountered, but these were left in the feeders to be consumed with the following day's ration. First weighing of the animals took place on the last day of adjustment of phase 1, and the second, 16 days later, at conclusion of phase 2 .

\section{RESULTS AND DISCUSSION}

TRIAL 1

Table 1 shows amounts of material ingested, voided in feces, and apparently digested in both experimental phases. Daily consumptions of DM, expressed either as percentages of liveweight or per unit of metabolic weight $\left(\mathrm{W}^{.75}\right)$, were low. Although the hay was of reasonably good digestibility (DM, $58.5 \pm 1.2 \%$; calories, $56.2 \pm 1.3$ ) and supplied $2.24 \mathrm{kcal}$

\footnotetext{
${ }^{6}$ Torrado Solub-Mol, Inc., Hatillo, P.R., whose generous help is acknowledged.

${ }^{7}$ Scales, F. M. and H. E. Harrison. 1920. Boric acid modification of the Kjeldahl method for crop and soil analysis. J. Ind. Eng. Chem. 12:350.
} 
TABLE 1.-Daily consumption, fecal elimination and apparent digestion of dry matter by individual animals during the collection periods of the two trials

\begin{tabular}{|c|c|c|c|c|c|c|c|c|}
\hline \multirow{2}{*}{ Animal } & \multicolumn{4}{|c|}{ Trial 1-Solub Mol } & \multicolumn{4}{|c|}{ Trial 2-Rum Distiller's Solubles } \\
\hline & 1 & 2 & 3 & 4 & 1 & 3 & 5 & 6 \\
\hline & \multicolumn{8}{|c|}{ Phase 2} \\
\hline Hay consumption (kg) & 2.167 & 1.898 & 2.348 & 2.607 & 2.340 & 2.580 & 2.340 & 2.460 \\
\hline DM content of hay $(\%)$ & \multicolumn{4}{|c|}{88.5} & \multicolumn{4}{|c|}{88.6} \\
\hline DM consumed in hay $(\mathrm{kg})$ & 1.918 & 1.679 & 2.078 & 2.307 & 2.073 & 2.286 & 2.073 & 2.180 \\
\hline DM eliminated in feces (kg) & .779 & .653 & .854 & 1.028 & .963 & 1.045 & .963 & .988 \\
\hline DM apparently digested (kg) & 1.139 & 1.026 & 1.224 & 1.279 & 1.110 & 1.241 & 1.110 & 1.192 \\
\hline DM consumed (\% liveweight) & 1.18 & 1.21 & 1.14 & 1.08 & 1.08 & .99 & 1.35 & .98 \\
\hline \multirow[t]{2}{*}{ DM consumed $\left(\mathrm{g} / \mathrm{W}^{.75}\right)$} & 42.0 & 41.5 & 41.9 & 41.2 & 40.2 & 38.6 & 47.2 & 37.9 \\
\hline & \multicolumn{8}{|c|}{ Phase 1} \\
\hline DM consumed in hay $(\mathrm{kg})$ & 1.918 & 1.679 & 2.078 & 2.307 & 2.073 & 2.286 & 2.073 & 2.180 \\
\hline Liquid feed consumption $(\mathrm{kg})$ & 1.773 & 1.552 & 1.922 & 2.133 & 1.560 & 1.720 & 1.560 & 1.640 \\
\hline DM content of liquid feed $(\%)$ & \multicolumn{4}{|c|}{44.2} & \multicolumn{4}{|c|}{53.3} \\
\hline DM consumed in liquid feed $(\mathrm{kg})$ & .784 & .686 & .849 & .943 & .831 & .917 & .831 & .874 \\
\hline DM eliminated in feces $(\mathrm{kg})$ & .992 & .882 & 1.052 & 1.298 & 1.323 & 1.481 & 1.410 & 1.461 \\
\hline \multicolumn{9}{|l|}{ Fecal DM derived from liquid feed } \\
\hline$(\mathrm{kg})$ & .213 & .229 & .198 & .270 & .360 & .436 & .447 & .473 \\
\hline DM digested from liquid feed ( $\mathrm{kg}$ ) & .571 & .457 & .651 & .673 & .471 & .481 & .384 & .401 \\
\hline DM consumed (\% liveweight) & 1.52 & 1.56 & 1.47 & 1.39 & 1.37 & 1.35 & 1.73 & 1.25 \\
\hline DM consumed $\left(g / W^{.75}\right)$ & 55.5 & 54.7 & 55.1 & 54.2 & 52.2 & 53.1 & 62.1 & 49.4 \\
\hline
\end{tabular}


of digestible energy (DE)/g of DM, it was deficient in digestible crude protein (DCP), 3.2\% in the DM. Consequently, all animals lost weight during the trial. Mean loss per animal was $16.2 \mathrm{~kg}$ (from 190.9 to 174.7 $\mathrm{kg}$ ), equivalent to $.75 \pm 0.07 \mathrm{~kg}$ daily. Obviously, the level of nutrition was considerably below maintenance requirements.

Mean digestibility coefficients for Solub Mol (table 2) were DM, 72.0; organic matter (OM), 71.1; and calories, 72.5. The digestibilities of these three fractions agree closely. Organic matter constituted $86.4 \%$ of the DM in Solub Mol, and the gross energy (GE) value was $4.44 \mathrm{kcal} / \mathrm{g}$ of $\mathrm{DM}$. Digestible organic matter (DOM) and DE contents in the DM were $61.4 \%$ and $3.22 \mathrm{kcal} / \mathrm{g}$, respectively. The latter figure can be compared, for example, with cane molasses, having a table value of $3.17 \mathrm{kcal}$ of $\mathrm{DE} / \mathrm{g}$ of $\mathrm{DM}^{8}$. The OM of Solub $\mathrm{Mol}$ contained $5.14 \mathrm{kcal}$ of $\mathrm{GE}$ and $3.73 \mathrm{kcal}$ of $\mathrm{DE} / \mathrm{g}$. Thus, this product merits classification as a concentrate feed, in view of its high digestibility and energy values.

The CP content of Solub Mol on a dry basis was $12.1 \%$ (table 2), but this fraction showed the low digestibility of $33.2 \%$, thus there was only $4.0 \%$ of DCP in the DM. To account for the marked effect that excretion of MFN exerts on apparent digestibility of CP in rations of low protein content, we estimated the true digestibility of this fraction, assuming MFN equal to $4.8 \mathrm{~g} / \mathrm{kg}$ of DM consumed ${ }^{9}$. This procedure led to an estimate of $58.3 \pm 3.6 \%$ for true $\mathrm{CP}$ digestibility, which corresponds to a true DCP content of $7.1 \%$ in the DM. This figure indicates that Solub $\mathrm{Mol}$ is still inadequate as a source of $\mathrm{DCP}$ for bovines.

The Solub Mol used in this trial had a specific gravity of 1.208. One gallon (3.78 liters), which is the unit of sale, would, therefore, weigh 4.58 $\mathrm{kg}$, and according to the present results, supply 6.50 Mcal of DE. The price per gallon paid by farmers was .45 dollar at the time of this study (late 1978), which means a cost of .069 dollar/Mcal of DE, competitive with costs of DE supplied by solid concentrate feeds, on the local market at this time.

\section{TRIAL 2}

The quantitative data on consumption, fecal elimination and apparent digestion during both experimental phases are in table 1 . The hay used in this trial proved to be even more deficient in DCP (2.6\% in the DM) than that of trial 1 , and was also lower in digestibility of DM $(54.0 \pm .3 \%)$ and of calories (51.9 $\pm .2 \%)$, supplying $2.10 \mathrm{kcal}$ of DE/g of DM. Lower

\footnotetext{
${ }^{8}$ National Research Council (NRC). 1978. Nutr. Req. Domestic Anim. No. 3. Nutr. Req. Dairy Cattle, 5th ed, Nat. Acad. Sci., Washington, D. C.

${ }^{9}$ McDonald, P., R. A. Edwards and J. F. D. Greenhalgh. 1973. Animal Nutrition, 2nd ed, Longman Group Ltd., London.
} 
TABLE 2.-Composition and apparent digestibility of the liquid feeds evaluated in the two trials

\begin{tabular}{|c|c|c|c|c|c|c|c|c|}
\hline \multirow[b]{2}{*}{ Fraction } & \multicolumn{4}{|c|}{ Trial 1-Solub Mol } & \multicolumn{4}{|c|}{ Trial 2-Rum Distiller's Solubles } \\
\hline & $\begin{array}{c}\text { Dry } \\
\text { mater }\end{array}$ & $\begin{array}{c}\text { Organic } \\
\text { mater }\end{array}$ & Energy & $\begin{array}{c}\text { Crude } \\
\text { protein }\end{array}$ & Dry mater & $\begin{array}{c}\text { Organic } \\
\text { mater }\end{array}$ & Energy & $\begin{array}{c}\text { Crude } \\
\text { protein }\end{array}$ \\
\hline & $\%$ & $\%$ & $\mathrm{kcal} / \mathrm{g}$ & $\%$ & $\%$ & $\%$ & $\mathrm{kcal} / \mathrm{g}$ & $\%$ \\
\hline \multicolumn{9}{|l|}{ Coefficient of digestibility } \\
\hline Mean & 72.0 & 71.1 & $72.5^{1}$ & 33.2 & 50.3 & 43.7 & $47.7^{1}$ & 40.6 \\
\hline Standard error & 2.2 & 2.3 & $2.2^{1}$ & 2.4 & 2.6 & 3.6 & $3.7^{1}$ & 5.6 \\
\hline Limits of $95 \%$ confidence & $62-82$ & $58-84$ & $62-83^{1}$ & $20-46$ & $45-56$ & $35-52$ & $40-56^{1}$ & $17-64$ \\
\hline Gross content in liquid form & 44.2 & 38.2 & 1.96 & 5.3 & 53.3 & 41.4 & 1.97 & 4.6 \\
\hline Digestible content in liquid form & 31.8 & 27.2 & 1.42 & 1.8 & 26.8 & 18.1 & .94 & 1.9 \\
\hline Gross content in DM & 100.0 & 86.4 & 4.44 & 12.1 & 100.0 & 77.6 & 3.70 & 8.6 \\
\hline Digestible content in DM & 72.00 & 61.4 & 3.22 & 4.0 & 50.3 & 33.9 & 1.76 & 3.5 \\
\hline Gross content in OM & 一 & 100.0 & 5.14 & 14.0 & - & 100.0 & 4.85 & 11.1 \\
\hline Digestible content in OM & 一 & 71.1 & 3.73 & 4.6 & - & 43.7 & 2.31 & 4.5 \\
\hline
\end{tabular}

${ }^{\mathrm{I}}$ Expressed as percent. 
nutritional value of the hay, combined with lower DM consumptions as a percentage of liveweight, contributed to more rapid liveweight loss in trial 2. The mean loss per animal was $15.8 \mathrm{~kg}$ (from 215.3 to $199.5 \mathrm{~kg}$ ), equivalent to $.99 \pm .23 \mathrm{~kg}$ daily.

Mean digestibility results for CMS (table 2) were DM, 50.3\%; OM, 43.7\%; and calories, $47.7 \%$. Organic matter comprised $77.6 \%$ of the DM, and DOM comprised $33.9 \%$. The GE and DE contents of the DM were 3.70 and $1.76 \mathrm{kcal} / \mathrm{g}$, respectively. Crude protein made up $8.6 \%$ of the DM, and with a mean digestibility of $40.6 \%$ for this fraction, there was $3.5 \%$ of DCP in the DM. True digestibility of the CP, estimated in the same way as in trial 1 , was $75.4 \pm 6.4 \%$, corresponding to a true DCP content of $6.5 \%$ in the DM.

In contrast to Solub Mol, CMS is far below the concentrate feeds in digestibility and DE values, being about on the level of fair-quality forages. Its contribution of DCP is also modest, although it nitrogenous fraction gave some indication of being slightly more digestible than that of Solub Mol. This evaluation of CMS is in disagreement with that of Paulino and Randel ${ }^{10}$, who studied the digestibility of four rations, composed principally of ground maize and ground hay plus $0,10,20$ or $30 \%$ of CMS. In that experiment it was concluded that the DM and several other fractions of CMS were more digestible than those of the other ration ingredients. That conclusion appears to have been incorrect in view of the present results.

Condensed molasses solubles have no local market price, not being sold commercially. However, the manufacturer of the material used in this trial $^{11}$ estimated a processing cost of .033 dollar $/ \mathrm{kg}$ of product, as of late 1978. If CMS supplied .94 Mcal of DE/kg (table 2), the cost per Mcal of DE therein would be .035 dollar, if it were sold at a price sufficient to cover only the cost of processing. In this case, it would be competitive as a source of DE. However, inclusion of a high proportion of CMS in the ration would not be feasible, because of its limited animal acceptance and low concentration of utilizable energy. It could be useful as a source of some nutrients at a moderate level in the ration.

\section{RESUMEN}

En dos pruebas de digestibilidad por el método de diferencia, utilizando 4 toretes castrados y períodos de 5 días de recolección total de las heces, se evaluaron dos alimentos líquidos: Solub Mol [un producto comercial compuesto de $70 \%$ de fracciones solubles de estreptomicetos

\footnotetext{
${ }^{10}$ Paulino, J. J. and P. F. Randel, 1975, Digestibilidad del mosto condensado. A.L.P.A. Mem. 10:43 (Abstr.).

${ }^{11}$ Bacardí Corp., Cataño, P.R., whose cooperation is gratefully acknowledged.
} 
y $30 \%$ de melaza de caña, con $44.2 \%$ de materia seca (MS) (DM)] y mosto condensado de la destilación de ron, con 53.3\% de MS. En la fase 1 de cada prueba la ración consistió de una mezcla de heno molido y el alimento líquido correspondiente, en las proporciones centesimales 55 heno: 45 Solub Mol ó 60 heno: 40 mosto. Las proporciones a base seca fueron 71 heno: 29 alimento líquido en ambas pruebas. Se restringió la ración a un $90 \%$ del consumo ad líbitum. En la fase 2 de cada prueba se eliminó al alimento líquido, manteniendo el suministro de heno igual que en la fase 1.

Se hallaron las siguientes digestibilidades medias en el Solub Mol: materia seca, $72.0 \pm 2.2 \%$; materia orgánica $(\mathrm{OM})(\mathrm{MO}), 71.1 \pm 2.3 \%$; calorías, $72.5 \pm 2.2 \%$; y proteína bruta (CP) (CP), $33.2 \pm 2.4 \%$. Los contenidos de energía digerible (DE) (ED) y proteína bruta digerible (CDP) (DCP) en la DM (MS) fueron $3.22 \mathrm{kcal} / \mathrm{g}$ y $4.0 \%$, respectivamente. Se estimó la digestibilidad verdadera de la CP en $58.3 \pm 2.6 \%$, correspondiendo a $7.1 \%$ de CDP en la DM. El Solub Mol puede clasificarse como una fuente concentrada de energía digerible, pero su fracción nitrogenada es de baja digestibilidad.

Se determinaron las siguientes digestibilidades medias en el mosto condensado: materia seca, $50.3 \pm 2.6 \%$; material orgánica, $43.7 \pm$ $3.6 \%$; calorías, $47.7 \pm 3.7 \%$; y proteína bruta, $40.6 \pm 5.6 \%$. Los contenidos de DE y CDP en la DM del mosto fueron $1.76 \mathrm{kcal} / \mathrm{g}$ y $3.5 \%$, respectivamente. La digestibilidad real estimada de la CP fue de 75.4 $\pm 6.4 \%$, correspondiendo a $6.5 \%$ de CDP real en la DM. El mosto condensado es un suplidor módico de energía y proteína para los bovinos. 